\title{
Examining the Effectiveness of Stem Cell and Platelet- Rich Plasma Therapies for Treating Osteoarthritis in Dogs
}

\author{
Hilty $\mathrm{DH}^{1}$, Yocum $\mathrm{JG}^{2}$ and Gallicchio $\mathrm{VS}^{3 *}$ \\ ${ }^{1}$ Calhoun Honors College, Clemson University, Clemson, USA \\ ${ }^{2}$ Green Tree Animal Hospital, Lexington, Kentucky, USA \\ ${ }^{3}$ Department of Biological Sciences, Microbiology, and Public Health Sciences College of Science and College of Health Sciences, Clemson University, Clemson, USA
}

\begin{abstract}
Regenerative medicine has quickly become an accepted medical therapeutic option for an ever-increasing array of clinical disorders. We report here a study evaluating the ability of adipose-derived mesenchymal stem cells and platelet-rich plasma to treat osteoarthritis in dogs. The study used eight dogs, treating 15 joints total. Each animal was evaluated prior to treatment, and then at intervals of $15,30,60$, and 90 days post-treatment. The evaluations scored each dog for lameness in walking and trotting; testing range of motion and pain upon manipulation; and observing functional disability of each joint. Statistical significance was obtained in multiple evaluation measures of the treatment outcomes, warranting further investigation of the healing capabilities of adipose-derived mesenchymal stem cells and plateletrich plasma as substantial components of regenerative medicine.
\end{abstract}

\section{Introduction}

Regenerative medicine is an expanding field of study that has the potential to impact the treatment of medicine as significantly as vaccines and antibiotics [1]. Stem cells and platelet-rich plasma (PRP) are increasingly used each year, especially in areas involving regeneration, e.g., orthopedics and oral and maxillofacial surgery [2]; however, the full potential of regenerative medicine is expected to reach far beyond what has been achieved thus far [3]. This study tested the capabilities of two popular regenerative medicine therapies by using them to treat osteoarthritis in dogs.

The two regenerative medicine therapies tested were platelet-rich plasma therapy and autologous adipose-derived mesenchymal stem cell (ADMSC) therapy. Platelet-rich plasma therapy involves the collection and injection of blood platelets plus plasma into a desired location. This therapy is based on the presence of numerous growth factors in platelet-enriched plasma; when activated, these have the ability to speed healing of the target by promoting growth in the specific area injected. Although stem cells can be collected from various body fluids and tissues, ADSMCs were used in this study due to the abundance of stem cells in adipose tissue, convenience of collection, and low-risk factors associated with collection.

Adipose tissue contains numerous stem cells and is stored in high amounts in the body. Bone marrow, another popular source for stem cell harvesting, contains high concentrations of pluripotent stem cells, but requires a much more painful and invasive procedure for harvesting. Using autologous derived-stem cells is both a convenient and safer method than using cells from a non-genetically identical donor animal. By using the subject's own cells, there is little risk of rejection when the transplant is injected into the subject [4].

\section{Materials and methods}

Eight dogs were studied, with varying degrees of osteoarthritis. Ages ranged from 4 to 11 years, and the size and breeds selected were very diverse, with small and large dogs in each group. Each dog was initially scored for lameness in the affected site during walking and trotting, with possible scores ranging from "not detectable" to "nonambulatory." Range of motion was scored from "no limitation" to pain at any attempt to manipulate joint" and pain upon manipulation of the joint was scored from "no pain" to "severe pain," (indicated by immediate limb withdrawal). The final data point recorded was functional disability, with scores ranging from normal activity to aversion to walking, needing assistance to stand from lying down, and inability to run". After scoring in each category, radiographs were taken of each subject. Each dog was then treated with either ADMSCs or PRP, with a total of eight joints treated with PRP and seven with ADMSCs. Five of the test subjects had multiple joints treated. In total: five stifles were treated with PRP and three with ADMSCs; two hips were treated with PRP and three with ADMSCs; one elbow was treated with PRP and one elbow was treated with ADMSCs. All data collection and treatments were performed at Green Tree Animal Hospital in Lexington, Kentucky, spanning the months June to November 2016.

PRP treatments consisted of collecting $36 \mathrm{cc}$. of whole blood from the jugular vein into four Vacutainers ${ }^{\varpi}$ containing $0.5 \mathrm{ml}$ of Anticoagulant Citrate Dextrose (ACD) solution A. The blood was centrifuged at $160 \mathrm{rpm}$ for 20 minutes using an InGeneron $\mathrm{ARC}^{\circ}$ Tissue Processing Unit; platelets remained in plasma, but all other cells collect at the bottom of the Vacutainer ${ }^{\circledR}$ tube. The plasma was drawn off and re-spun at $600 \mathrm{rpm}$ for 10 minutes to collect the platelets in a pellet at the bottom of the tube. The supernatant was drawn off and discarded leaving 5 total volume. Each dog was sedated and PRP was injected directly into the joint.

Correspondence to: Vincent S Gallicchio, Department of Biological Sciences, Microbiology, and Public Health Sciences College of Science and College of Health Sciences, Clemson University, Clemson, E-mail: vsgall@clemson.edu

Key words: mesenchymal stem cells, platelet-rich plasma, osteoporosis, dogs

Received: November 22, 2017; Accepted: December 06, 2017; Published: December 09, 2017 
ADSMC treatment required anesthesia for collection and sedation for injection. Collection occurred in the fatty tissue posterior to the left shoulder. After the dog was anesthetized, the area of collection was shaved and sterilized. A small incision was made at the site, a Tulip "cell friendly" lipoaspiration cannula was inserted, and $60 \mathrm{ml}$ of saline was injected from a $120 \mathrm{cc}$. Toomey collection syringe, with a low percentage of lidocaine included for increased numbing. The infused tissue was disrupted to dislodge the adipose cells. The mixture was drawn back out through the cannula, and injected into a collection tube from an $\mathrm{ARC}^{\circledR}$ Tissue Processing System. Matrase ${ }^{\mathrm{TM}}$ Reagent was added to release the stem cells from the adipose tissue, and was centrifuged according to the InGeneron instructions (InGeneron, n.d.) [5]. The top layer of the mixture was drawn off and discarded as waste, and the remainder was filtered. The mixture was twice washed with saline and filtered, before centrifuging at a high rate to form a pellet of only stem cells at the bottom of the container. The stem cell pellet was combined with $2 \mathrm{ml}$ of saline and injected directly into the joint of a sedated dog, identical according to the PRP procedure. Adipose tissue processed by the InGeneron ARC ${ }^{\mathrm{TM}}$ system typically yields millions of viable cells, with a very high proportion being mesenchymal stem cells [6].

Each dog was retested and scored after 15, 30, 60, and 90 days. Any changes in medically relevant factors, such as medication or additional injuries, were noted.

\section{Results}

One dog was removed from the study, because the owner failed to respond to follow-up requests. Another dog was removed from the 90day trial because cranial cruciate surgery was needed, which precluded proper evaluation. Both excluded dogs were treated with stem cells. Table 1 shows the scoring criteria for each evaluation in this study. The scores were averaged over all subjects with each criterion and graphed in Figures 1 to 10.

\section{Results and discussion}

As seen in Figures 1 to 10, the average conditions of the canines improved greatly. This improvement continued through the 60 -day trials in all but four tests: walking lameness for stem cells, trotting lameness for both PRP and stem cells, and PRP functional disability. The PRP data were especially promising, because PRP is currently a much less expensive treatment.

For both the stem cell and PRP treatments, outcomes for subjects excelled in most categories when measured with an unpaired t-test for statistical significance $(\mathrm{p}<.05)$, even with the small sample size. The equation, shown in Figure 11, accounts for the sample sizes, standard deviations, and means of the data. The significance was calculated for the change between the results in each category from the 0 -day scoring to the 90 -day scoring.

In stem cell treated dogs, the p-value was $\leq 0.0025$ in a t-test of walking lameness data from day 0 to day 90. PRP-treated dogs had an observed p-value of less than 0.0002 for the same period. Both values obtained equated to extreme statistical significance, while taking into account the small sample size. This indicates potential benefits for both forms of regenerative medicine.

The stem cell treatment data had a p-value of $\leq 0.0020$ when a $\mathrm{t}$-test was performed on the trotting lameness data from day 0 to day 90, while the PRP treatment data for trotting lameness over the same period yielded a $p$-value of $\leq 0.0002$. These values equated to very and extremely statistically significant respectively.

The range of motion for stem cell treatment $t$-test values were not as promising; the p-value was 0.1135 , which is not close to significant. The PRP treatment data for range of motion was much better, with a statistically significant $p$-value of $\leq 0.0014$. The 0 -day scores for two PRP-treated dogs and one stem cell evaluations for range of motion were 1 , which limited the data analysis, as no improvement was possible. Excluding the dogs that started with scores of one for range of motion, the $\mathrm{p}$-value for the stem cells obtained significance with a value of 0.0474 . The stem cell-treatment results also showed a decrease in range of motion from 60 to 90 days; it is possible the effects of the stem cells began to decrease, but the small sample size precludes conclusion.

Results for pain upon manipulation were similar to range of motion results. The stem cell p-value equaled 0.1340 . The stem cell-

Table 1. Scoring criteria used to assess effectiveness of procedure at days $0,15,30,60$, and 90 . Scoring criteria based on study performed by [7]

\begin{tabular}{|c|c|c|c|c|c|c|}
\hline & $\begin{array}{c}\text { Not } \\
\text { Detectable }\end{array}$ & Intermittent & Persistent & $\begin{array}{c}\text { Persistent } \\
\text { non-weight } \\
\text { bearing }\end{array}$ & $\begin{array}{c}\text { Ambulatory } \\
\text { only with } \\
\text { assistance }\end{array}$ & $\begin{array}{c}\text { Non- } \\
\text { ambulatory }\end{array}$ \\
\hline $\begin{array}{l}\text { Lameness: } \\
\text { walk }\end{array}$ & 1 & 2 & 3 & 4 & 5 & 6 \\
\hline \multirow[t]{2}{*}{$\begin{array}{l}\text { Lameness: } \\
\text { trot }\end{array}$} & 1 & 2 & 3 & 4 & 5 & 6 \\
\hline & \multicolumn{2}{|c|}{ No pain } & \multicolumn{2}{|c|}{$\begin{array}{l}\text { Mild pain (attempts to } \\
\text { withdraw limb) }\end{array}$} & \multicolumn{2}{|c|}{$\begin{array}{c}\text { Severe } \\
\text { (immediate limb } \\
\text { withdrawal) }\end{array}$} \\
\hline \multirow[t]{2}{*}{$\begin{array}{l}\text { Pain upon } \\
\text { manipulation }\end{array}$} & \multicolumn{2}{|c|}{1} & \multicolumn{2}{|c|}{2} & \multicolumn{2}{|c|}{3} \\
\hline & \multicolumn{2}{|c|}{ No limitation } & $\begin{array}{l}\text { Pain only at full } \\
\text { range of motion }\end{array}$ & $\begin{array}{l}\text { Pain at less than } \\
\text { full range of } \\
\text { motion }\end{array}$ & \multicolumn{2}{|c|}{$\begin{array}{c}\text { Pain at any } \\
\text { attempt to } \\
\text { manipulate joint }\end{array}$} \\
\hline \multirow[t]{2}{*}{$\begin{array}{l}\text { Range of } \\
\text { motion }\end{array}$} & \multicolumn{2}{|c|}{1} & 2 & 3 & \multicolumn{2}{|c|}{4} \\
\hline & $\begin{array}{l}\text { Normal } \\
\text { activity }\end{array}$ & $\begin{array}{l}\text { Slightly stiff } \\
\text { gait. Only } \\
\text { noticeable while } \\
\text { running }\end{array}$ & $\begin{array}{l}\text { Stiff. Dog has } \\
\text { noticeable } \\
\text { difficulty } \\
\text { walking or } \\
\text { running }\end{array}$ & $\begin{array}{l}\text { Very stiff. Dog } \\
\text { does not want } \\
\text { to walk or run } \\
\text { unless coaxed }\end{array}$ & \multicolumn{2}{|c|}{$\begin{array}{l}\text { Dog does not } \\
\text { want to } \\
\text { walk, must } \\
\text { be helped up, } \\
\text { and does not } \\
\text { run }\end{array}$} \\
\hline $\begin{array}{c}\text { Functional } \\
\text { disability }\end{array}$ & 1 & 2 & 3 & 4 & \multicolumn{2}{|c|}{5} \\
\hline
\end{tabular}




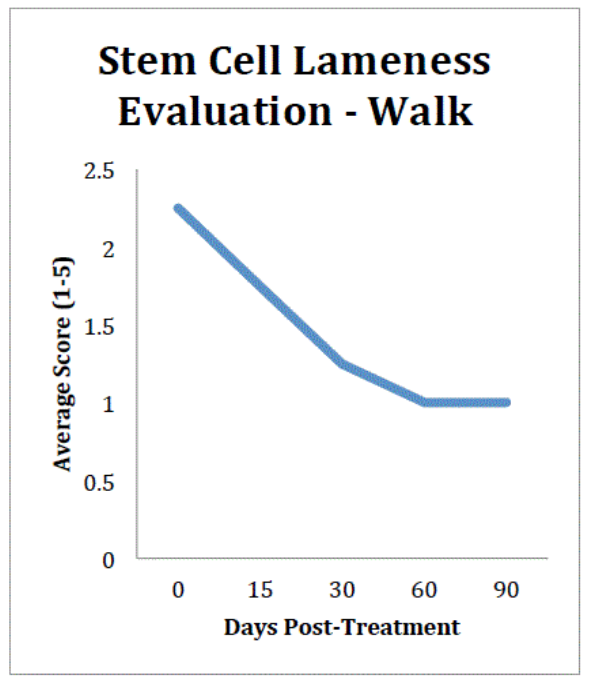

Figure 1. Stem cell walking lameness evaluation results from the day of treatment to 90 days post-treatment.

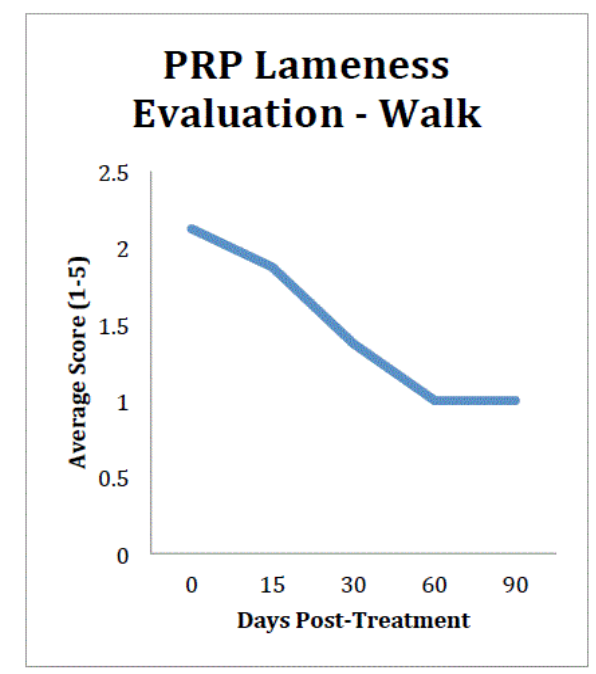

Figure 2. PRP walking lameness evaluation results from the day of treatment to 90 days post-treatment.

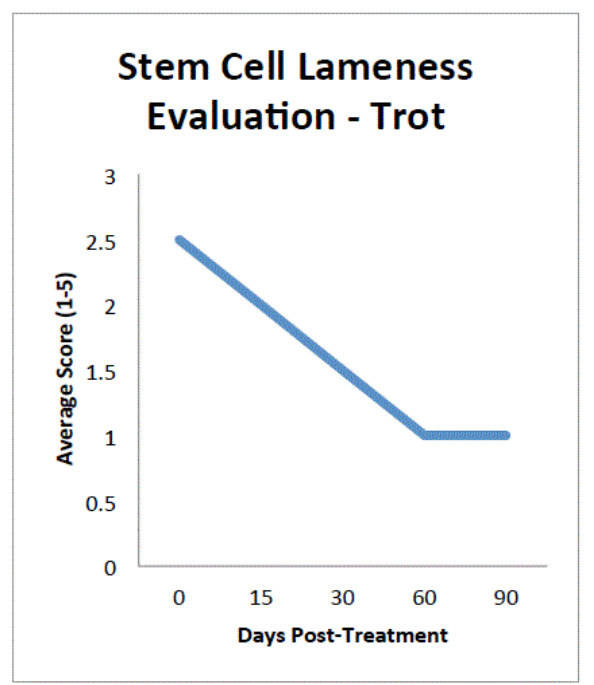

Figure 3. Stem Cell trotting lameness evaluation results from the day of treatment to 90 days post-treatment.

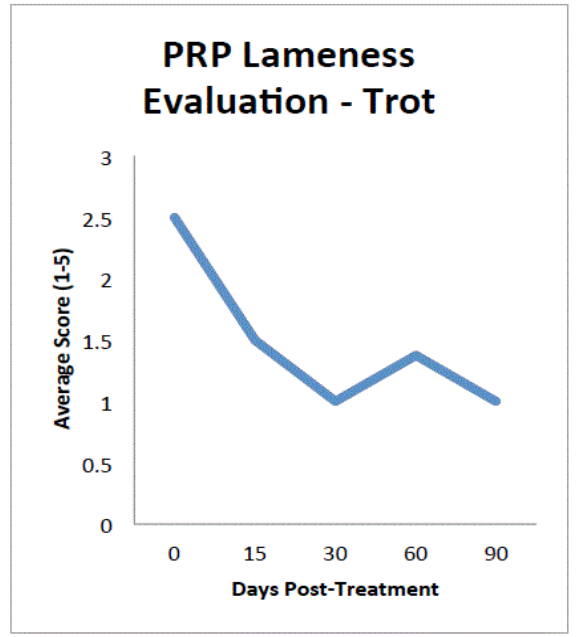

Figure 4. PRP trotting lameness evaluation results from the day of treatment to 90days post-treatment.

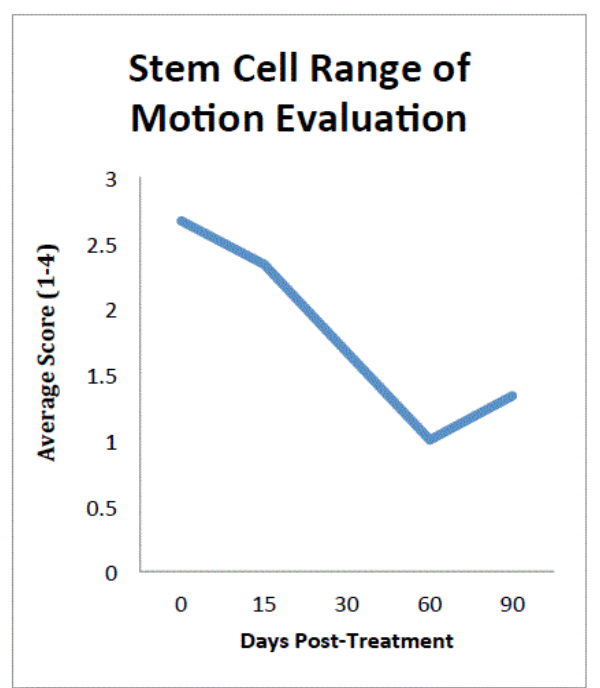

Figure 5. Stem cell range of motion evaluation results from the day of treatment to 90 days post-treatment. Dog with initial score of 1 removed from graph.

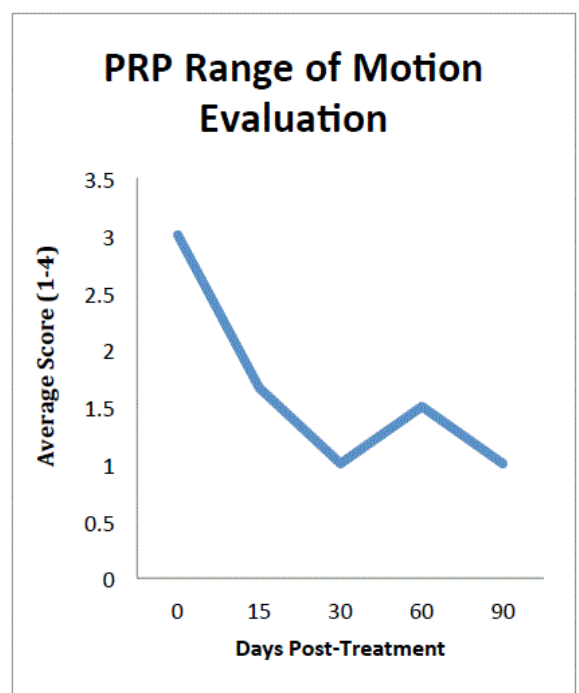

Figure 6. PRP range of motion evaluation results from the day of treatment to 90 days posttreatment. Dogs with initial score of 1 removed from graph. 


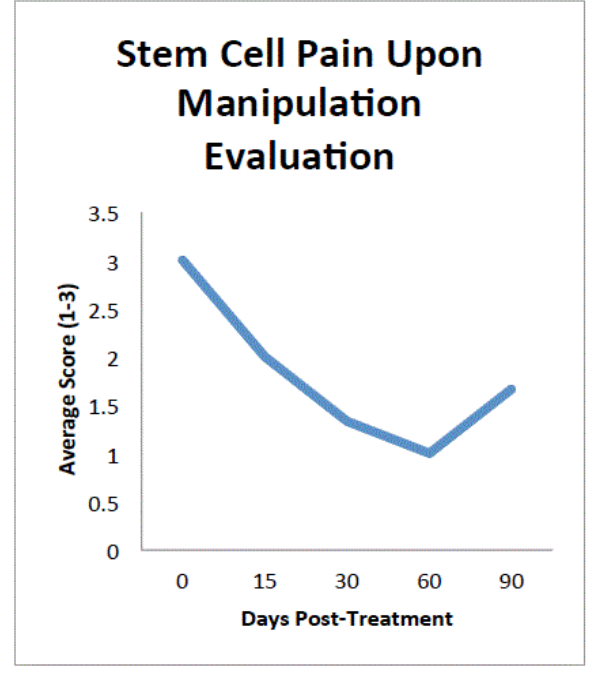

Figure 7. Stem cell pain upon manipulation evaluation results from the day of treatment to 90 days post-treatment. Dog with initial score of 1 removed from graph.

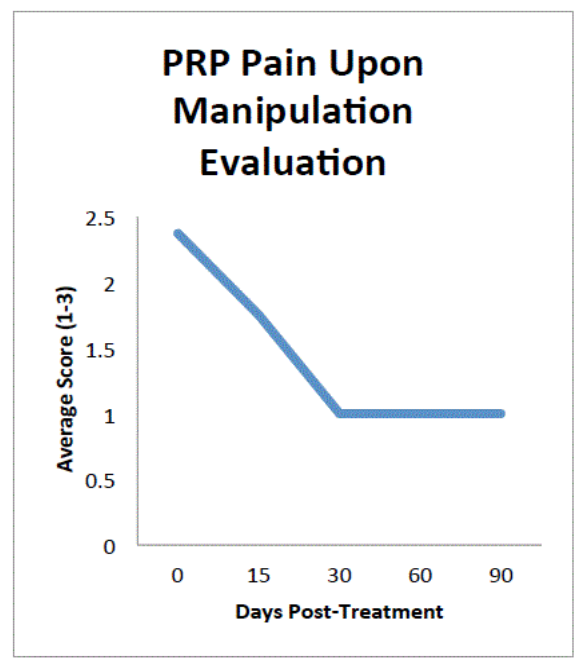

Figure 8. PRP pain upon manipulation evaluation result from the day of treatment to 90 days post-treatment.

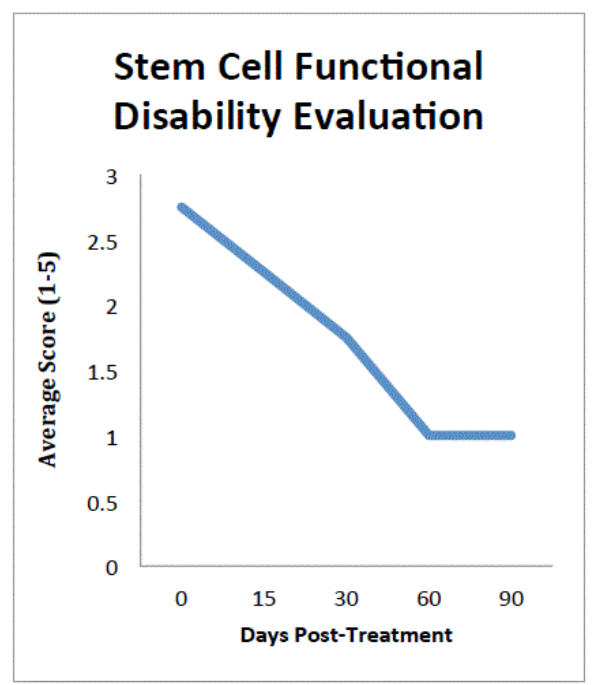

Figure 9. Stem cell functional disability evaluation results from the day of treatment to 90 days post-treatment.

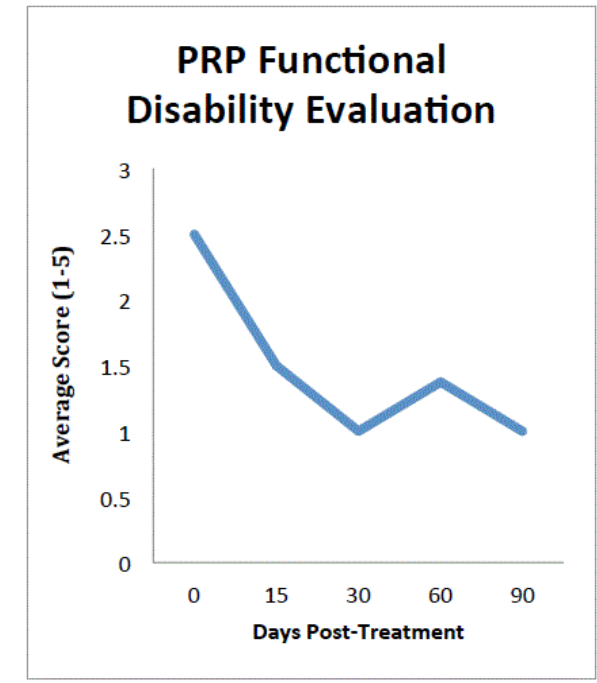

Figure 10. PRP functional disability evaluation results from the day of treatment to 90 days post-treatment.

$$
t=\frac{\left(x_{1}-x_{2}\right)}{\sqrt{\frac{\left(s_{1}\right)^{2}}{\mathrm{n}_{1}}+\frac{\left(\mathrm{s}_{2}\right)^{2}}{\mathrm{n}_{2}}}}
$$

Figure 11. Equation for unpaired t-test. $\mathrm{x} 1$ and $\mathrm{x} 2$ stand for the means of the first and second set of scores. S1 and S2 stand for the standard deviations of each set, and $\mathrm{n} 1$ and $\mathrm{n} 2$ stand for the number of values in each set. Higher t-statistic values correspond to higher significance.

treatment group started with one dog having "1" as the initial value, indicating normal function, and no improvement possible; when this dog was excluded from the calculation, the stem cell p-value was 0.0161, which is statistically significant. The PRP-treated group had a $\mathrm{p}$-value of 0.0001 for the pain upon manipulation data, indicating extreme significance.

The most important facet of the testing was the score of functional disability, as an indicator of degree to which the symptoms interfere with daily life. Both stem cell and PRP treatments showed significant potential in this category. The stem cells had a p-value $<0.0004$, and the $\mathrm{PRP}$ had one of $<0.0008$ over the 0 to 90 -day period, which both equate to extreme significance.

This outcome provides evidence that both treatments were extremely successful at treating osteoarthritis in multiple joints. That significance is observed in such a small sample size indicates a strong reason to further investigate regenerative medicine across more fields at a larger scale, with more subjects, and across multiple species.

\section{Disclosure}

The authors acknowledge no conflict of interest.

\section{References}

1. Polak JM, Mantalaris S (2008) Stem cells bioprocessing: an important milestone to move regenerative medicine research into the clinical arena. Pediatr Res 63: 461-466. [Crossref]

2. Lin SS, Landesberg R, Chin HS, Lin J, Eisig SB, et al. (2006) Controlled release of PRPderived growth factors promotes osteogenic differentiation of human mesenchymal stem cells. Engineering in Medicine and Biology Society, 2006. EMBS'06. 28th Annual International Conference of the IEEE. IEEE.

3. Chen FH, Tuan RS (2008) Mesenchymal stem cells in arthritic diseases. Arthritis Res Ther 10: 223. [Crossref] 
Hilty DH (2017) Examining the Effectiveness of Stem Cell and Platelet-Rich Plasma Therapies for Treating Osteoarthritis in Dogs

4. Tögel F, Cohen A, Zhang P, Yang Y, Hu Z, et al (2009) Autologous and allogeneic marrow stromal cells are safe and effective for the treatment of acute kidney injury. Stem Cells Dev 18: 475-486. [Crossref]

5. In Generon Process. InGeneron.

6. Dominici M, Le Blanc K, Mueller I, Slaper-Cortenbach I, Marini F, et al. (2006)
Minimal criteria for defining multipotent mesenchymal stromal cells. The International Society for Cellular Therapy position statement. Cytotherapy 8: 315-317. [Crossref]

7. Black LL, Gaynor J, Gahring D, Adams C, Aron D, et al. (2007) Effect of adiposederived mesenchymal stem and regenerative cells on lameness in dogs with chronic osteoarthritis of the coxofemoral joints: a randomized, double-blinded, multicenter controlled trial. Vet Ther 8: 272-284. [Crossref]

Copyright: ( 2017 Hilty DH. This is an open-access article distributed under the terms of the Creative Commons Attribution License, which permits unrestricted use, distribution, and reproduction in any medium, provided the original author and source are credited. 